\title{
The Vertical Distribution of Zooplankton in Relation to Habitat Zones in the Area of the Atlantis II Deep, Central Red Sea
}

\author{
H. Weikert \\ Institut für Hydrobiologie und Fischereiwissenschaft der Universität Hamburg, Zeiseweg 9, D-2000 Hamburg 50, Federal \\ Republic of Germany
}

\begin{abstract}
The vertical distribution of mesozooplankton has been studied in the central Red Sea to determine its relationship to discrete habitat zones defined according to density, oxygen and nutrient concentrations, seston, and phytoplankton profiles. A disproportionately large amount of the $300 \mu \mathrm{m}$ net plankton occurs both day and night in the epipelagic zone, which occupies the upper water layer above the abrupt thermohalocline at about $100 \mathrm{~m}$. In contrast, in the lower bathypelagic zone, a layer between 1,050 and $\geq 1,850 \mathrm{~m}$, the numerical abundance and biomass of the zooplankton $(0.2$ specimens and $\leq 0.05 \mathrm{mg}$ wet weight $\mathrm{m}^{-3}$ ) correspond to values encountered in other oligotrophic regions in tropical oceans below a depth of 4,000 to $6,000 \mathrm{~m}$. The subsurface zooplankton maximum is situated in the core of the oxygen minimum layer, which is located in the mesopelagic zone (100 to $750 \mathrm{~m}$ ). Minimum oxygen values at ca. $400 \mathrm{~m}$ delimit the upper and lower interzonal (mesopelagic) assemblages. The unusual plankton distribution, the predominance of a few species and the ontogenetic segregation of the interzonal species are related to the abnormally high temperature $\left(\geq 21.5^{\circ}\right)$ and salinity $(\geq 40.5 \%$ S) in the subsurface waters, coupled with a depleted oxygen content in the mesopelagic zone and lack of food in the bathypelagic zone. Vertical transport of organic matter is achieved by the ladder of migrations; involving a few interzonal species that descend into the upper bathypelagic zone but remain above ca. $1,100 \mathrm{~m}$. Transport of organic debris below this depth by sinking is ineffective because its decay is too rapid.
\end{abstract}

\section{INTRODUCTION}

In contrast to that of the Gulf of Aqaba (Kimor and Golandsky, 1977; Klinker et al., 1978; LevanonSpanier et al., 1979; Winter et al., 1979), the planktonic community of the Red Sea proper has not yet been well investigated ecologically. Most of the information available on the planktonic biota concerns primarily the morphological, systematic and biogeographic aspects (inter alia: Casanova et al., 1973; Ducret, 1973 . 1974; Godeaux, 1974; Weigmann, 1974; Por, 1978). Halim (1969) reviewed the older literature. Quantitative studies had been restricted to primary production measurements (Khmeleva, 1970), general numerical analyses of phytoplankton (Sukhanova, 1969), and determinations of total volumes and wet weights of zooplankton in the upper $1,000 \mathrm{~m}$ (Delalo, 1966; Ponomareva, 1968; Gordeyeva, 1970). Nevertheless, the quantity of plankton in this sea cannot yet be reliably estimated (Kimor, 1973). The present knowledge about the planktonic community in the Red Sea proper, including preliminary quantitative information on seasonal structural changes in the zooplankton, has been summarized by Weikert (in press). Like the present paper, this summary is based on results obtained from an ecological study of the pelagic zone in the central Red Sea that is being continued under the supervision of the author. The study is part of the Metalliferous Sediments Development Programme Atlantis II Deep (MESEDA), initiated by the SaudiSudanese Red Sea Joint Commission, Jeddah.

The first synoptic study of the plankton and its environment was conducted aboard the R.V. 'Sonne' from October 30 to November 14, 1977, above and in the vicinity of the Atlantis II Deep (Fig. 1). Findings concerning the ecological significance of the oxygen minimum layer in this area and considerations on adaptive mechanisms of some of its most conspicuous 
zooplankton species have been published recently (Weikert, 1980). The objectives of the present study were the assessment of zooplankton standing stock and composition, its distribution according to habitat zones, and its diel vertical migrations. A general picture of the sequence of vertical migration in the central Red Sea is given, and comments are made on the energy flux in the water column.

\section{MATERIAL AND METHODS}

Zooplankton was collected at 11 stations in the area of the Atlantis II Deep. Three additional stations were located near the Sudanese reef region (Fig. 1). There were no significant differences in total zooplankton abundance and vertical distribution of species, so the samples from the different locations are not considered separately in this study.

The collecting device was an improved Bé opening and closing net (MCN) equipped with a pressure meter (Weikert and John, 1981). Temperature and conductiv-

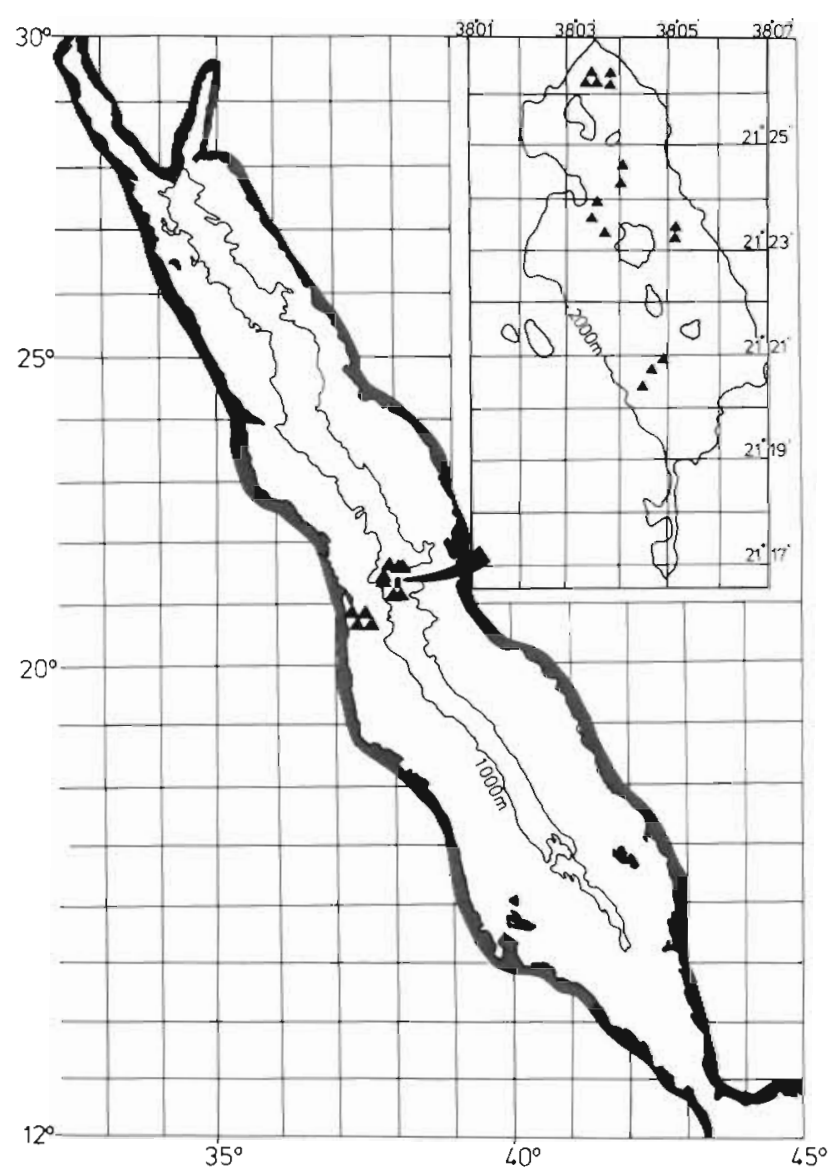

Fig. 1. Sites of plankton sampling in the Red Sea, November 1977. Enlarged section of map shows position of stations above Atlantis II Deep ity were recorded immediately before or after the $\mathrm{MCN}$ tows with a bathysonde. The five $300 \mu \mathrm{m}$ nets of the MCN (mouth opening $0.5 \times 0.5 \mathrm{~m}$ ) are operated via a one-conductor cable in a way that closing one net opens the next one in the sequence. The stratified vertical tows were conducted to $1,850(1,900) \mathrm{m}$; thus, they commenced about $100 \mathrm{~m}$ from the surface of the hot saline brines that fill the basin (Bäcker and Schoell, 1972). The sequence of depth intervals was every $50 \mathrm{~m}$ from 0 to $450 \mathrm{~m}$, every $150 \mathrm{~m}$ from 450 to $1,050 \mathrm{~m}$, and every $200 \mathrm{~m}$ from 1,050 to $1,850 \mathrm{~m}$. During daylight, the deepest samples were taken from 1,450 to $1,700 \mathrm{~m}$. In 3 cases, the 450 to $600 \mathrm{~m}$ layer was sampled at $50 \mathrm{~m}$ intervals. The total of 207 samples were taken at 8 stations around midday and 6 stations at about midnight at a towing speed of $1 \mathrm{~ms}^{-1}$. During these periods, diel migrants are generally thought to remain at constant depth levels. An indication of this is the position of the deep scattering layer, DSL (Weikert, in press), which showed no change during the 4 to $5 \mathrm{~h}$ daytime collecting period. Nevertheless, some vertical movement of animals has to be expected (Roe, 1974).

The zooplankton was preserved in $4 \%$ formaldehyd seawater solution buffered with hexamethylenetetramine. The total number of organisms was determined, excluding exoskeletons or animals that were obviously dead prior to collection. The non-living specimens, which were almost exclusively copepods, were distinguished according to the criteria of Wheeler (1967) and Weikert (1977). When it seemed necessary for a clearer presentation of the results, counts of samples from below $1,050 \mathrm{~m}$ were given with corrections for contaminants, together with the original values. The contamination estimates (Weikert and John, 1981) were corroborated by recent investigations comparing vertical and horizontal tows, the latter yielding markedly smaller proportions of the following taxa: Appendicularia; Gastropoda (veligers); certain Pteropoda Euthecosomata, and Copepoda. Organisms may have entered in shallow water while the closed nets were being retrieved, or they may not have been removed when the nets were washed down after the preceding haul (Bernhard et al., 1973). Wet weight was measured by the method of Tranter (1962) after removal of occasional coelenterates and salps larger than $0.5 \mathrm{~cm}$.

The depth ranges in which at least 50,75 and $97.5 \%$ of the individuals belonging to a given taxon occurred were determined by adding percentages from layers which contained the largest proportions of specimens. In general, there was a steady decrease in numbers from the layer of maximum occurrence. The $50 \%$ of the population nearest the distribution centre is referred to as the population core. No interpolations were made. Therefore, in particular in the case of calculations to locate $75 \%$ of the populations, the depth range given 
often includes even more than $75 \%$. The actual percentages are given separately in the figures. Instead of calculating the depth range for $100 \%$ of the population, $97.5 \%$ was used to compensate for the ca. $2.5 \%$ contamination factor (Weikert and John, 1981).

The phytoplankton-nutrient complex was investigated in water samples taken with 51 Niskin samplers at $5,15,30,50,75,100,150,200,250$, and $300 \mathrm{~m}$. A water volume of 31 sample $^{-1}$ was used for the immediate chlorophyll a determination, the data of which are being published separately (Weikert, in press). The remainder of the water was analyzed for phosphate and silicate by the methods of Koroleff (Grasshoff, 1976) and for oxygen by the Winkler method.

Water for the determination of seston was taken by regular hydrocasts from $5 \mathrm{~m}, 15 \mathrm{~m}$; every $50 \mathrm{~m}$ from depths of 50 to $1,100 \mathrm{~m}_{i}$ and every $100 \mathrm{~m}$ from 1,250 to $1,850 \mathrm{~m}$. From the 51 Niskin samplers, 31 of water were filtered through a $2.5 \mathrm{~mm}$ diameter glass fibre filter (Whatman GF/C), dry frozen and stored under silica gel in plastic petri dishes. The dry weights of the seston, organic substance content, and ash (inorganic substance) were determined ashore by the methods of Postma (1954) and Lenz (1971). The remaining water was analyzed for nutrients and oxygen (see above).

\section{RESULTS}

\section{The Abiotic Environment}

The discrete habitat zones in the water column of the Atlantis II Deep area can be recognized in Figs. 2, 3, and 4 .

The Red Sea is an extraordinary 2-layer sea with elevated temperatures of about $21.5^{\circ}$ to $22.0{ }^{\circ} \mathrm{C}$ at depths greater than 150 to $200 \mathrm{~m}$ (Morcos, 1970). In

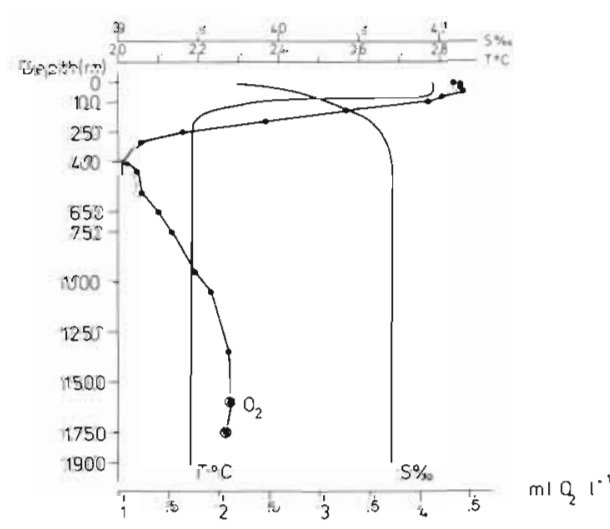

Fig. 2. Profiles of mean dissolved oxygen, temperature and salinity in the area of the Atlantis II Deep. T and S redrawn from bathysonde computations. Circle around a point denotes an uncertain mean concentration
November 1977, in the area of the Atlantis II Deep, sharp temperature and salinity gradients (Fig. 2) between about 75 and $180 \mathrm{~m}$ separated a shallow zone of extremely warm surface water $\left(27.7^{\circ} \mathrm{C}\right.$ and $39.73 \%$ S) from the isothermal and isohaline deep water body $\left(21.7^{\circ} \mathrm{C}\right.$ and $40.67 \%$ S).

Within the narrow surface zone, 2 maxima of chlorophyll a occurred, one at about $5 \mathrm{~m}$ and the other from 50 to $75 \mathrm{~m}$ (Weikert, 1981, in press, in prep.). This means that the subsurface maximum of photosynthetic pigments was close to or within the upper part of the discontinuity layer. Within the surface layer, the highest oxygen concentrations $\left(\bar{x}=4.44 \mathrm{ml} \mathrm{O}_{2} \mathrm{l}^{-1}\right)$ were found at a depth of $50 \mathrm{~m}$, indicating that there was a biological supply of oxygen from photosynthesis and that at least part of the subsurface chlorophyll a was contained in active cells. Similar subsurface maximum concentrations of oxygen in the Red Sea were reported by Grasshoff (1969).

The bottom of the euphotic layer includes the top of the thermohalocline. Judging from Secchi disc readings $\left(D_{m}\right)$, that varied from 28 to $31.5 \mathrm{~m}$, the $1 \%$ level of surface light intensity ranged from approximately 75 to $85 \mathrm{~m}$, assuming an extinction coefficient of $\mathrm{k}=1.7$ $\left(D_{m}\right)^{-1}$ (Smith, 1976). The photic layer, approximately the upper $90 \mathrm{~m}$, was sampled by the MCN at two $50 \mathrm{~m}$ intervals. This somewhat arbitrary $100 \mathrm{~m}$ layer is called the epipelagic zone (Vinogradov, 1968).

Following Vinogradov's scheme of biological zonation, the adjacent 100 to $750 \mathrm{~m}$ layer is called the mesopelagic zone. Unlike in the common terminology, the discontinuity layer is included since it exhibits environmental and zooplanktonic features that are typical for the mesopelagic zone.

The mesopelagic zone is characterized by remineralization processes. As indicated by the oxygen and nutrient profiles (Fig. 3) most decomposition

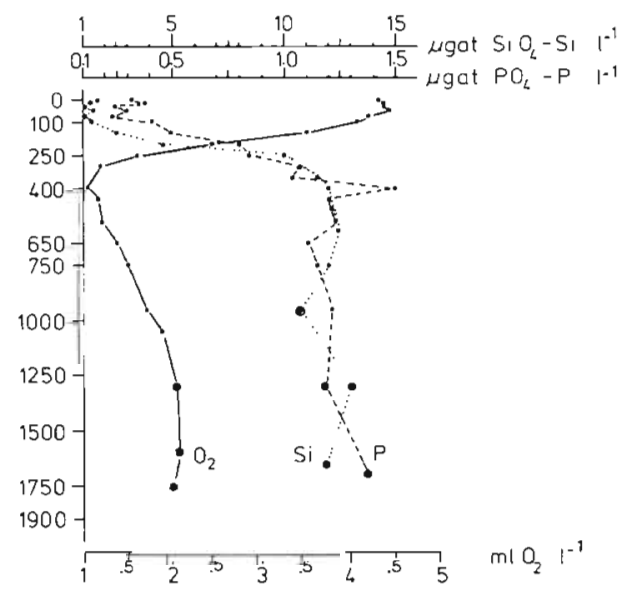

Fig. 3. Profiles of mean concentrations of phosphate, silicate and oxygen in the area of the Atlantis II Deep. Circle around a point denotes an uncertain concentration 
of organic material takes place in the 100 to $250 \mathrm{~m}$ layer. The result is a sharp decrease in oxygen content from $\geq 4 \mathrm{ml} \mathrm{O}_{2} 1^{-1}$ to $1.6 \mathrm{ml} \mathrm{O}_{2} 1^{-1}$ at a depth of $250 \mathrm{~m}$, associated with the decline in particulate organic matter (POM), as shown in Fig. 4. The average POM values decrease from $0.157 \mathrm{mgl}^{-1}(67 \%$ of the seston) in the upper $50 \mathrm{~m}$ to $0.120 \mathrm{mg} \mathrm{l}^{-1}$ (57\% of the seston) in the oxycline.

Below the zone of sharp oxygen gradients (>250 m), the core of the oxygen minimum layer extends approximately from $300 \mathrm{~m}$ to $650 \mathrm{~m}$ (Fig. 3). The average oxygen concentrations of 1.3 to $0.9 \mathrm{ml} \mathrm{O}_{2} \mathrm{l}^{-1}$ within the core are clearly distinguishable from values above $250 \mathrm{~m}$ (one-way analysis of variance, $\mathrm{p}=0.01$, Weikert, 1980). This is paralleled by the differences in POM (one-way analysis of variance, $p=0.05$ ). The lowest oxygen concentrations coincide with minimum POM concentrations of $0.80 \mathrm{mgl}^{-1}$ at $550 \mathrm{~m}$ to 0.90 $\mathrm{mg} \mathrm{l}^{-1}$ at $400 \mathrm{~m}$. About $54 \%$ of the seston is POM (Fig. 4). An absolute increase in POM, which increases to $64 \%$ of the seston near the bottom of the oxygen minimum core at $650 \mathrm{~m}$, could not be verified statistically.

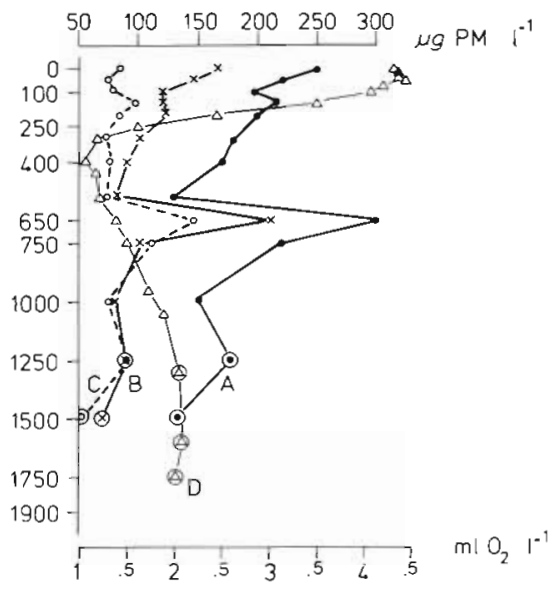

Fig. 4. Profiles of mean oxygen and particulate matter (seston) concentrations in the area of the Atlantis II Deep. Seston (A), POM (B), ash (C), oxygen (D). Circle around a point denotes an uncertain concentration

The decomposition of organic matter below $100 \mathrm{~m}$ leads to an increase in inorganic nutrients with depth. Phosphate increases from $0.3 \mu \mathrm{g}$ at $1^{-1}$ in the surface layer to a maximum of $1.5 \mu \mathrm{g}$ at $1^{-1}$ in the core of the oxygen minimum layer (Fig. 3). The corresponding values for silicate are $1.3 \mu \mathrm{g}$ at $l^{-1}$ and $12.4 \mu \mathrm{g}$ at $l^{-1}$.

Below the core of the oxygen minimum layer $(>650 \mathrm{~m})$, there is a slight increase in oxygen and nutrient concentrations. Although the significance of these findings is reduced because of the relatively small data set (see encircled points in Fig. 3), there are similarities with findings from earlier investigations (Morcos, 1970). As documented in the present paper, the water below $750 \mathrm{~m}$ is distinguished by a strongly reduced zooplankton activity. Thus, it exhibits a feature typical of the bathypelagic zone (Hedgepeth, 1957; Vinogradov, 1968).

\section{Vertical Distribution and Abundance of Mesozoo- plankton}

Concentration and Standing Stock of Total Zooplankton

The vertical distribution of the mesozooplankton and its biomass (Fig. 5) corresponds to the divisions of the
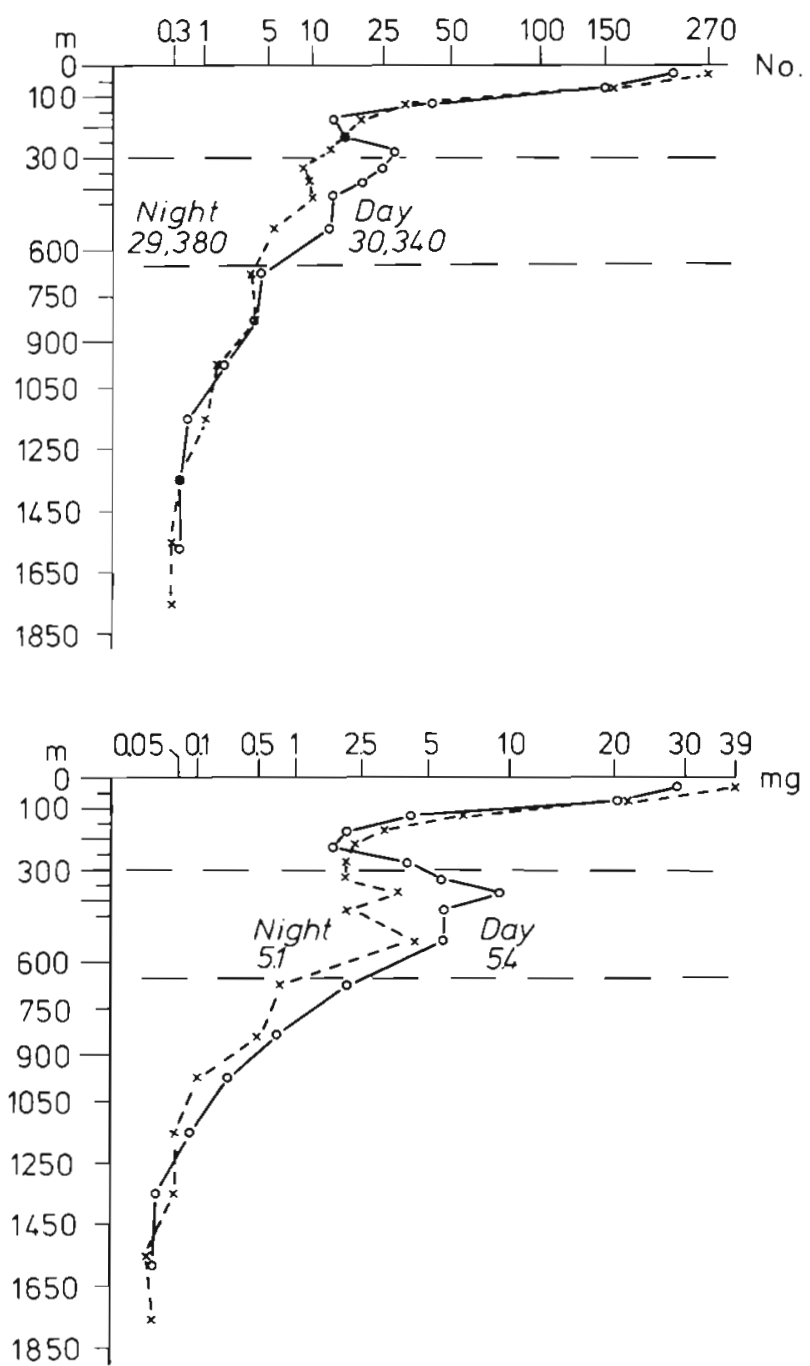

Fig. 5. Mean midday and midnight profiles of $300 \mu \mathrm{m}$ net zooplankton individual numbers and wet weight biomass $\mathrm{m}^{-3}$ (cube root scale). Numbers beside curves denote standing stock 
environment. Most of the zooplankton was concentrated in the upper $100 \mathrm{~m}$, the epipelagic zone. The abundance and biomass averaged from combined values for both day and night amounted to 200 specimens $\mathrm{m}^{-3}$ and $27 \mathrm{mg}$ wet weight $\mathrm{m}^{-3}$ Such low values are characteristic of oligotrophic environments (Vinogradov, 1968)

There was a strong planktocline from about 100 to $150 \mathrm{~m}$ that tends to coincide with the thermocline and the oxycline. This sharp decline may be a characteristic of the central Red Sea that distinguishes the region from other oligotrophic, tropical regions. Significant numerical and biomass ratios between the upper $100 \mathrm{~m}$ and underlying layer at 100 to $200 \mathrm{~m}$ amounting to about $7: 1$ were found, during day and night (Table 1). Data available for $65 \mu \mathrm{m}$ net zooplankton collected at a single station in the same area (Gordeyeva, 1970) yielded similar ratios, 8.7:1 for numbers and 5.4:1 for biomass. In contrast, ratios of values for mesozooplankton biomass reported from the tropical Indo-Pacific Region (Vinogradov, 1968) and the Sargasso Sea (Yashnov, 1961; Ortner et al., 1978) range between $3.4: 1$ and $0.7: 1$.

Table 1. Central Red Sea. Ratios of wet weight and individual numbers of mesozooplankton in the upper $100 \mathrm{~m}$ to those in the 100 to $200 \mathrm{~m}$ layer. Comparative values for oligotrophic parts of the Indopacific Region provided by Vinogradov (1968, Tabs. 18, 20)

\begin{tabular}{|lcccc|}
\hline & \multicolumn{2}{c}{ Numbers } & \multicolumn{2}{c|}{ Biomass } \\
& Mean & Range & Mean & Range \\
\hline Red Sea & & & & \\
$\quad$ Day & $7.0: 1$ & $4.7: 1-13.4: 1$ & $7.9: 1$ & $4.0: 1-15.8: 1$ \\
$\quad$ Night & $7.9: 1$ & $5.2: 1-11.7: 1$ & $6.6: 1$ & $4.8: 1-17.3: 1$ \\
Pacific Ocean & - & - & $1.9: 1$ & $1.2: 1-3.4: 1$ \\
Indian Ocean & - & - & $1.8: 1$ & $0.7: 1-2.8: 1$ \\
\hline
\end{tabular}

A secondary concentration of zooplankton occurred in the mesopelagic zone, in the core of the oxygen minimum layer. Maximum numbers, averaging 20 specimens $\mathrm{m}^{-3}$ were congregated in the 250 to $300 \mathrm{~m}$ layer, whereas the maximum biomass of $5 \mathrm{mg} \mathrm{m}^{-3}$ was found in the 350 to $600 \mathrm{~m}$ layer. The disjunction of numerical and biomass maxima is attributed to the larger mean size of the species living in the lower part of the mesopelagic zone, from which strongest sound scattering has been recorded (Weikert, in press). Faecal material of the animals in this zone may have been the source of the concentration peak of POM at $650 \mathrm{~m}$ (Fig. 4).

Organisms were extremely scarce in the bathypelagic zone, especially below $1,050 \mathrm{~m}$ (Fig. 5). The average sample contained about $0.05 \mathrm{mg}$ wet weight
Table 2. Central Red Sea. Standing stock of $300 \mu \mathrm{m}$ net zooplankton (mesozooplankton) at different depths

\begin{tabular}{|ccc|}
\hline Depth (m) & Numbers $\mathrm{m}^{-2}$ & Wet weight $\left(\mathrm{g} \mathrm{m}^{-2}\right)$ \\
\hline $0-100$ & 19,864 & 2.72 \\
$100-750$ & 8,860 & 2.35 \\
$750-1850$ & 1,156 & 0.21 \\
Total & 29,880 & 5.28 \\
\hline
\end{tabular}

and 0.4 specimens $\mathrm{m}^{-3}$. A minimum concentration of 0.2 specimens and less than $0.04 \mathrm{mg}$ biomass $\mathrm{m}^{-3}$ were found in the 1,450 to $1,850 \mathrm{~m}$ layer.

Table 2 shows that $66 \%$ of the mesozooplanktonic organisms live in the upper $100 \mathrm{~m}$. About $96 \%$ of the total net plankton and a similar proportion of biomass were collected from the upper $750 \mathrm{~m}$ of the water column. However, due to the large size of subsurface species, the amount of biomass $\mathrm{m}^{-2}$ in the mesopelagic zone was almost the same as in the epipelagic. Of the remaining $4 \%$ confined to the bathypelagic zone, $75 \%$ of the individuals and $86 \%$ of the biomass were collected from the top 750 to $1,050 \mathrm{~m}$. The exclusion of contaminants from samples deeper than $1,050 \mathrm{~m}$ resulted in an average concentration of 0.2 specimens $\mathrm{m}^{-3}$, only $0.4 \%$ of the standing stock in the entire water column.

\section{Standing Stocks and Abundances of Major Groups}

In contrast to other deep-sea regions, no one major taxonomic group was found to be abundant in the zooplankton below $750 \mathrm{~m}$ (Table 3 ). The zooplankton groups in the central Red Sea displayed a strong affinity for the $100 \mathrm{~m}$ epipelagic layer, the percentages of the total stocks in the water column generally ranging between $71 \%$ and $99 \%$. Smaller proportions of the ostracods $(48 \%)$, chaetognaths $(56 \%)$, copepods (59\%), euphausiids (61\%), and pteropods (61\%) occurred in the surface layer. All of these were also collected in relatively large numbers of the mesopelagic zone. The term 'interzonal', as introduced by Vinogradov (1968), is applied to species living there.

Copepods formed the bulk of the mesozooplankton both in the surface and deep water habitats (Table 4). As in the case of ostracods and decapods, their relative abundance in the plankton increased with depth, i.e. from $48 \%$ in the surface layer to more than $60 \%$ in the mesopelagic and bathypelagic zones. These percentages are about $20 \%$ less than those reported for samples from the northern Sargasso Sea obtained with 202 and $363 \mu \mathrm{m}$ nets (Deevey and Brooks, 1977).

Calanoids, in general, comprised $64 \%$ to $68 \%$ of the 
Table 3. Distribution of standing stock of major mesozooplankton taxa according to habitat zones. Abundances in each zone expressed as percentages of total individuals in the entire water column

\begin{tabular}{|c|c|c|c|c|}
\hline Taxon & $\begin{array}{c}\text { Epipelagic } \\
\text { zone (J) } \\
0-100 \mathrm{~m}\end{array}$ & $\begin{array}{l}\text { I and mesopelagic } \\
\text { zone (II) } \\
0-750 \mathrm{~m}\end{array}$ & $\begin{array}{c}\text { I, II and upper } \\
\text { bathypelagic zone } \\
0-1050 \mathrm{~m}\end{array}$ & $\begin{array}{c}\text { Average } \\
\text { No. }\left(0.25 \mathrm{~m}^{2}\right)^{-1}\end{array}$ \\
\hline Foraminifera & 91 & 99 & 99 & 1140 \\
\hline Siphonophora & 82 & 97 & 100 & 202 \\
\hline Coelenterates, others & 83 & 99 & 100 & 209 \\
\hline Cladocera & 100 & $\cdot$ & & 3 \\
\hline Ostracoda & 48 & 92 & 99 & 474 \\
\hline Cirripedia & 100 & $\cdot$ & & 2 \\
\hline Copepoda & 59 & 95 & 99 & 4067 \\
\hline Amphipoda & 71 & 100 & & 42 \\
\hline Isopoda & $\cdots$ & $\cdots$ & & 2 \\
\hline Mysidacea & $\cdots$ & $\cdots$ & $\cdots$ & 2 \\
\hline Euphausiacea & 61 & 100 & & 70 \\
\hline Decapoda & 94 & 100 & & 22 \\
\hline Pteropoda & 61 & 98 & 100 & 108 \\
\hline Heteropoda & 86 & 100 & & 10 \\
\hline Mollusca, others & 80 & 100 & $\cdot$ & 40 \\
\hline Polychaeta & 75 & 95 & 100 & 117 \\
\hline Chaetognatha & 56 & 97 & 98 & 535 \\
\hline Appendicularia & 88 & 100 & $\cdot$ & 215 \\
\hline Thaliacea & 99 & 100 & & 208 \\
\hline
\end{tabular}

Table 4. Relative abundances of major mesoplankton groups in different habitat zones (Numbers expressed as a percent of total individuals $100 \mathrm{~m}^{-3}$ within each zone)

\begin{tabular}{|c|c|c|c|c|}
\hline \multirow[t]{2}{*}{ Taxa } & \multirow{2}{*}{$\begin{array}{l}\text { Epipelagic zone } \\
\qquad-100 \mathrm{~m}\end{array}$} & \multirow{2}{*}{$\begin{array}{l}\text { Mesopelagic zone } \\
100-750 \mathrm{~m}\end{array}$} & \multicolumn{2}{|c|}{ Bathypelagic zone } \\
\hline & & & $\begin{array}{c}\text { upper } \\
750-1050 \mathrm{~m}\end{array}$ & $\begin{array}{c}\text { lower } \\
1050-1850 \mathrm{~m}\end{array}$ \\
\hline Foraminifera & 20.7 & 4.3 & 3.6 & 10.0 \\
\hline Siphonophora & 3.3 & 1.2 & 2.9 & 0.0 \\
\hline Coelenterates, others & 3.5 & 1.5 & 0.7 & 0.6 \\
\hline Cladocera & 0.05 & 0.01 & 0.0 & 0.0 \\
\hline Ostracoda & 3.9 & 6.5 & 17.3 & 7.0 \\
\hline Cirripedia & 0.03 & 0.04 & 0.0 & 0.0 \\
\hline Copepoda & 48.3 & 69.5 & 66.2 & 63.8 \\
\hline Amphipoda & 0.6 & 0.6 & 0.2 & 0.6 \\
\hline Isopoda & 0.02 & 0.1 & 0.0 & 0.0 \\
\hline Mysidacea & 0.03 & 0.01 & 0.0 & 0.6 \\
\hline Euphausiacea & 0.9 & 1.1 & 0.4 & 0.0 \\
\hline Decapoda & 0.5 & 0.2 & 0.9 & 1.3 \\
\hline Pteropoda & 1.3 & 2.1 & 0.7 & 0.0 \\
\hline Heteropoda & 0.2 & 0.1 & 0.2 & 0.0 \\
\hline Mollusca, others & 0.7 & 0.3 & 0.2 & $0.6^{*}$ \\
\hline Polychaeta & 1.8 & 1.0 & 2.0 & 0.6 \\
\hline Chaetognatha & 6.0 & 10.7 & 5.4 & 11.3 \\
\hline Appendicularia & 3.8 & 1.1 & 0.9 & $0.6^{\circ}$ \\
\hline Thaliacea & 4.1 & 0.2 & 0.0 & 0.0 \\
\hline Total plankters $100 \mathrm{~m}^{-3}$ & 19980 & 1656 & 278 & 40 \\
\hline - Contaminants & & & & \\
\hline
\end{tabular}

copepods in the upper $300 \mathrm{~m}$. At greater depths, this percentage increased to $89 \%$ in the 750 to $900 \mathrm{~m}$ layer.
If Oithona specimens, which comprise about $7 \%$ of the total copepods, are excluded as contaminants, the per- 
centage of calanoids at greater depths reaches $100 \%$. The relative abundance of the harpacticoids (Macrosetella gracilis) increased from about $0.4 \%$ in the epipelagic zone to an average of $3 \%$ in the 100 to $1,050 \mathrm{~m}$ layer.

About $70 \%$ of the cyclopoids belonged to Oithona; the remainder were corycaeids, oncaeids and sapphirinids. Oithona specimens formed a significant fraction of the mesozooplankton standing stock $(11 \%)$.

Foraminifera were conspicuous in surface waters, contributing $21 \%$ to the total epizooplankton (Table 4 ). Large individuals of $0.5-0.8 \mathrm{~mm}$ were predominant. Gordeyeva (1970) who used $65 \mu \mathrm{m}$ nets, reported a relative abundance of only $1.4 \%$ in the total zooplankton, but the concentrations $\mathrm{m}^{-3}$ were nearly the same in the upper $100 \mathrm{~m}$ : 36.4 specimens in October 1970 as compared to 41.4 specimens in November 1977. Based on these concentrations and the size distribution observed, it seems likely that the great abundance of foraminiferans in the $300 \mu \mathrm{m}$ samples is not a transitory bloom but rather a feature typical of the mesozooplankton in autumn. Other abundant groups in the epipelagic zone were coelenterates, chaetognaths and tunicates.

In the mesopelagic and bathypelagic zones, chaetognaths $(10.7 \%)$ and ostracods $(6.5 \%)$ followed the copepods in order of relative abundance.

\section{Distribution of Calanoid Copepod and Euthecosoma- tous Pteropod Populations}

For a better understanding of common features in the vertical structure of the central Red Sea zooplankton community, the abundance and occurrence of the most numerous group, the calanoids, was investigated (Table 5, Fig. 6). The euthecosomatous pteropods were included for comparison (Table 6).

In the central Red Sea, predominance of single species was a conspicuous feature of the zooplankton. Among the calanoid copepods, 3 taxa were predominant, comprising $50 \%$ of the total standing stock in the water column (55\% in the oceanic samples). They are Clausocalanus spp., Haloptilus longicornis, and

Table 5. Calanoid copepods. Midday concentrations of species $100 \mathrm{~m}^{-3}$ in various habitat zones. Parentheses: percentages of total concentration in a layer. St: Standing stock, averaged absolute and relative numbers per haul in the 0 to $1700 \mathrm{~m}$ water column

\begin{tabular}{|c|c|c|c|c|c|c|c|c|c|c|c|c|c|c|}
\hline \multirow{4}{*}{$\begin{array}{c}\text { Species } \\
\text { Calanus tenuicornis }\end{array}$} & \multirow{3}{*}{\multicolumn{2}{|c|}{$\begin{array}{l}\text { Epipelagic } \\
\text { zone } \\
0-100 \mathrm{~m}\end{array}$}} & \multirow{3}{*}{\multicolumn{2}{|c|}{$\begin{array}{l}\text { Oxycline } \\
100-250 \mathrm{~m}\end{array}$}} & \multirow{2}{*}{\multicolumn{4}{|c|}{$\begin{array}{l}\text { Mesopelagic zone } \\
\qquad \mathrm{O}_{2} \text {-Min. layer }\end{array}$}} & \multirow{2}{*}{\multicolumn{4}{|c|}{ Bathypelagic zone }} & & \\
\hline & & & & & & & & & & & & & & \\
\hline & & & & & \multicolumn{2}{|c|}{$\begin{array}{c}\text { Upper } \\
250-450 \mathrm{~m}\end{array}$} & \multicolumn{2}{|c|}{$\begin{array}{l}\text { Lower } \\
450-750 \mathrm{~m}\end{array}$} & \multicolumn{2}{|c|}{$\begin{array}{c}\text { Upper } \\
750-1050 \mathrm{~m}\end{array}$} & \multicolumn{2}{|c|}{$\begin{array}{c}\text { Lower } \\
1050-1700 \mathrm{~m}\end{array}$} & \multicolumn{2}{|c|}{$\begin{array}{c}\text { St: No } \\
\left(0.25 \mathrm{~m}^{2}\right)^{-1}:(\%)\end{array}$} \\
\hline & 43 & $(0.8)$ & 10 & $(0.9)$ & 0.3 & $(<0.1)$ & - & & - & & - & & 15 & $(0.5)$ \\
\hline Nannocalanus minor & 203 & $(3.6)$ & 3 & $(0.3)$ & 0.4 & $(<0.1)$ & $0.1^{\circ}$ & $(<0.1)$ & $0.1^{\circ}$ & $(<0.1)$ & - & & 53 & (1.9) \\
\hline Calanus pauper & 1 & $(<0.1)$ & - & & - & & - & & _- & & - & & 0.4 & $(0.1)$ \\
\hline Undinula vulgaris & 282 & $(4.8)$ & 0.2 & $(<0.1)$ & - & & - & & - & & - & & 69 & (2.4) \\
\hline Eucalanus spp. & 15 & $(0.3)$ & - & & 2 & $(0.2)$ & - & & - & & - & & 5 & $(0.2)$ \\
\hline Rhincalanus nasutus & _- & & - & & 6 & $(0.5)$ & 32 & $(7.5)$ & 0.4 & $(0.3)$ & - & & 27 & $(0.9)$ \\
\hline Mecynocera clausi & 483 & $(8.5)$ & 22 & $(2.1)$ & 18 & (1.6) & 7 & (1.6) & 2 & (1.3) & $0.9^{\circ}$ & $(5.2)$ & 146 & (5.1) \\
\hline Calocalanus spp. & 202 & (3.5) & 4 & $(0.4)$ & 3 & $(0.3)$ & 0.3 & $(0.1)$ & $0.4^{\circ}$ & $(0.3)$ & $0.1^{\circ}$ & $(0.6)$ & 54 & $(1.9)$ \\
\hline Clausocalanus spp. & 1909 & $(33.5)$ & 63 & (5.9) & 16 & (1.4) & 3 & $(0.7)$ & $4^{\circ}$ & $(2.5)$ & 2 & $(11.5)$ & 554 & (19.3) \\
\hline Euchaeta spp. & 34 & $(0.6)$ & 15 & (1.4) & 19 & $(1.7)$ & 6 & (1.4) & 0.5 & $(0.3)$ & $0.8^{\circ}$ & $(4.6)$ & 29 & $(1.0)$ \\
\hline Scolecithridae & - & & 0.4 & $(<0.1)$ & 106 & (9.5) & 72 & $(16.8)$ & 55 & (34.8) & 2 & (11.5) & 152 & (5.3) \\
\hline Temoropia mayumbaensis & 3 & $(0.1)$ & 32 & $(3.2)$ & 137 & (12.3) & 0.9 & $(0.2)$ & 0.9 & $(0.6)$ & $0.3^{\circ}$ & $(1.7)$ & 81 & $(2.8)$ \\
\hline Pleuromamma indica & 136 & (2.4) & 93 & (8.7) & 541 & $(48.4)$ & 204 & $(47.7)$ & 47 & $(29.7)$ & 5 & $(28.7)$ & 535 & (18.7) \\
\hline Centropages spp. & 432 & $(7.6)$ & 4 & $(0.4)$ & 4 & $(0.4)$ & 0.7 & $(0.2)$ & $0.2^{\circ}$ & $(0.1)$ & - & & 109 & (3.8) \\
\hline Lucicutia spp. & 312 & (5.5) & 53 & $(5.0)$ & 26 & $(2.3)$ & 3 & $(0.7)$ & 2 & (1.3) & -- & & 30 & $(1.1)$ \\
\hline L.paraclausi & - & & - & & 3 & $(0.3)$ & 21 & (4.9) & 16 & $(10.1)$ & 0.8 & (4.6) & 114 & $(4.0)$ \\
\hline Haloptilus acutifrons & - & & 0.2 & $(<0.1)$ & 26 & $(2.3)$ & 45 & $(10.5)$ & 5 & $(3.2)$ & 0.2 & $(1.2)$ & 357 & $(12.5)$ \\
\hline H. longicornis & 225 & (3.9) & 686 & $(64.5)$ & 67 & $(6.0)$ & 7 & (1.6) & 5 & (3.2) & $0.6^{\circ}$ & (3.2) & 11 & $(0.4)$ \\
\hline H. ornatus & - & & 5 & $(0.5)$ & 15 & (1.3) & 1 & $(0.2)$ & 0.7 & $(0.4)$ & - & & 33 & $(1.2)$ \\
\hline Euaugaptilus hecticus & - & & 3 & $(0.3)$ & 4 & $(0.4)$ & - & & - & & - & & 3 & $(0.1)$ \\
\hline $\begin{array}{l}\text { Candaciidae (mainly } \\
\text { P. truncata, C. catula) }\end{array}$ & 336 & (5.9) & 11 & $(1.0)$ & 9 & $(0.8)$ & 1 & $(0.2)$ & 1 & $(0.6)$ & $0.6^{\circ}$ & (3.5) & 95 & (3.3) \\
\hline Pontellina plumatas.l. & 20 & $(0.4)$ & 0.4 & $(<0.1)$ & 0.4 & $(<0.1)$ & - & & - & & - & & 5 & $(0.2)$ \\
\hline Calanopia sp. & 24 & $(0.4)$ & 5 & $(0.5)$ & - & & - & & - & & - & & 8 & $(0.3)$ \\
\hline Acartiidae & 490 & $(8.6)$ & 7 & $(0.7)$ & 6 & $(0.5)$ & 2 & $(0.5)$ & $2^{\cdot}$ & $(1.3)$ & $0.1^{\circ}$ & $(0.6)$ & 133 & (4.6) \\
\hline Unidentified & 557 & $(9.8)$ & 45 & $(4.2)$ & 109 & $(9.8)$ & 22 & (5.1) & 16 & $(10.1)$ & 4 & $(23.4)$ & 246 & $(8.6)$ \\
\hline Total & 5707 & $(100.3)$ & 1064 & $(100.0)$ & 1118 & $(100.0)$ & 428 & $(100.0)$ & 158.5 & $(100.1)$ & 17.5 & $(100.2)$ & 2864 & $(100.1)$ \\
\hline
\end{tabular}


Table 6. Relative distribution of euthecosomatous pteropod standing stock according to the various habitat zones. Normal type: midday distribution. Italics: midnight distribution. Parentheses: percentage abundances of the total concentration in a layer. St:

Standing stock (mean numbers) in the 0 to $1700 \mathrm{~m}$ water column

\begin{tabular}{|c|c|c|c|c|c|c|c|}
\hline \multirow[t]{3}{*}{ Species } & \multirow{2}{*}{$\begin{array}{c}\text { Epipelagic } \\
\text { zone }\end{array}$} & \multicolumn{3}{|c|}{ Mesopelagic zone } & \multicolumn{2}{|c|}{ Bathypelagic zone } & \multirow[b]{3}{*}{$\begin{array}{l}\text { St: No } \\
\left(0.25 \mathrm{~m}^{2}\right)^{-1}\end{array}$} \\
\hline & & \multirow{2}{*}{$\begin{array}{l}\text { Oxycline } \\
100-250 \mathrm{~m}\end{array}$} & \multicolumn{2}{|c|}{$\mathrm{O}_{2}$-Min. layer } & \multirow[b]{2}{*}{$\begin{array}{c}\text { Upper } \\
750-1050 \mathrm{~m}\end{array}$} & \multirow[b]{2}{*}{$\begin{array}{c}\text { Lower } \\
1050-1700 \mathrm{~m}\end{array}$} & \\
\hline & $0-100 \mathrm{~m}$ & & $\begin{array}{c}\text { Upper } \\
250-450 \mathrm{~m}\end{array}$ & $\begin{array}{c}\text { Lower } \\
450-750 \mathrm{~m}\end{array}$ & & & \\
\hline Limacina inflata & $1.2 \quad(3)$ & $5.0(64)$ & $91.6(85)$ & $1.6(83)$ & $0.6 \quad(50)$ & - & 56.7 \\
\hline & 95.1 & 0.5 & 2.3 & 1.0 & 1.1 & - & \\
\hline L. trochiformis & $92.7(58)$ & $6.0(14)$ & - & - & $1.3^{*}(30)$ & - & 16.8 \\
\hline & 99.2 & 0.8 & - & - & - & - & \\
\hline Creseis a acicula & $71.1 \quad$ (9) & $0.0 \quad(0)$ & $17.2 \quad(2)$ & $6.3(17)$ & $5.4^{*}(20)$ & - & 3.5 \\
\hline & 97.5 & 2.5 & - & - & - & - & \\
\hline Cr.v. virgula & $62.2 \quad(5)$ & $17.1 \quad$ (7) & $20.7 \quad(1)$ & - & - & - & 1.9 \\
\hline & 96.9 & 3.1 & - & - & - & - & \\
\hline Cr.spp. formae & 100 & - & - & - & - & - & 2.1 \\
\hline & 100 & - & - & - & - & - & \\
\hline Clio pyramidata & $15.4 \quad(5)$ & $3.8(15)$ & $80.8(11)$ & - & - & - & 8.7 \\
\hline & 79.3 & 8.0 & 2.0 & 2.3 & 4.4 & & \\
\hline Cavolinia inflexa & 100 & - & - & - & - & - & 2.2 \\
\hline & 100 & - & - & - & - & - & \\
\hline Cav.spp., & 100 & - & - & - & - & - & 1.4 \\
\hline $\begin{array}{l}\text { Diacria quadridentata, } \\
\text { Diacria sp. }\end{array}$ & 100 & - & - & - & - & - & \\
\hline Total No. $100 \mathrm{~m}^{-3}$ & 110 & 14 & 119 & 1.5 & 0.5 & - & 93.3 \\
\hline
\end{tabular}

Pleuromamma indica. The most abundant pteropods were Limacina trochiformis and L. inflata, which contribute $18 \%$ and $61 \%$, respectively, to the Euthecosomata stock.

During daylight, the principal species were segregated from each other in different habitat zones or in subzones. The relative abundance of the Clausocalanus species group, which primarily inhabits the epipelagic zone, was less than that of the interzonal species, Haloptilus longicornis and Pleuromamma indica, in their respective habitats. Similarly, among the pteropods, Limacina trochiformis comprised $58 \%$ of the surface dwelling shell-bearing species, whereas L. inflata formed $85 \%$ of a similar assemblage inhabiting the mesopelagic zone.

The increase in dominance of principal species below $100 \mathrm{~m}$ is coupled with an unusually low number of interzonal calanoids. Although all calanoids have not yet been identified to species, the total number of calanoid species in the water column apparently shows a general decrease with depth, as in the case of the euthecosomatous pteropods.

The distribution of populations of interzonal species, concentrated in a well-stratified region of abundance between 250 and $750 \mathrm{~m}$, where the water is isohaline and isothermal, fitted Cooper's (1967) concept that the vertical ranges of species in the deep ocean remain within uniform habitats. However, a peculiarity is that the resulting secondary maxima in diversity, biomass and individual numbers all lie in the core of the oxygen minimum layer.

In the oxycline $(100$ to $250 \mathrm{~m})$, the upper $50 \mathrm{~m}$ of which is characterized by sharp gradients of temperature and salinity, populations of calanoids and pteropods seem to avoid the discontinuity. The only exception was Haloptilus longicornis, which constituted $65 \%$ of the total calanoid numbers and $30 \%$ of the total $300 \mu \mathrm{m}$ net plankton in this part of the mesopelagic zone.

Pleuromamma indica, the principal species in the 250 to $750 \mathrm{~m}$ layer of the mesopelagic zone, contributed $48 \%$ of the calanoid specimens and $28 \%$ of the total mesozooplankters in this layer (Weikert, 1980). A number of interzonal species, however, were distributed only in the upper part of the oxygen minimum layer core, but disappeared or became rare below $450 \mathrm{~m}$. These include the pteropod, Limacina inflata, and the calanoids Eucalanus spp. (mainly E. attenuatus), Euaugaptilus hecticus, Temoropia mayumbaensis, and Haloptilus ornatus. In the deeper part of the oxygen minimum layer, extending from about $450 \mathrm{~m}$ to between 650 and $750 \mathrm{~m}$, pteropods, with the exception of Clio pyramidata, had disappeared. The stocks of the calanoid copepods, Haloptilus acutifrons, 

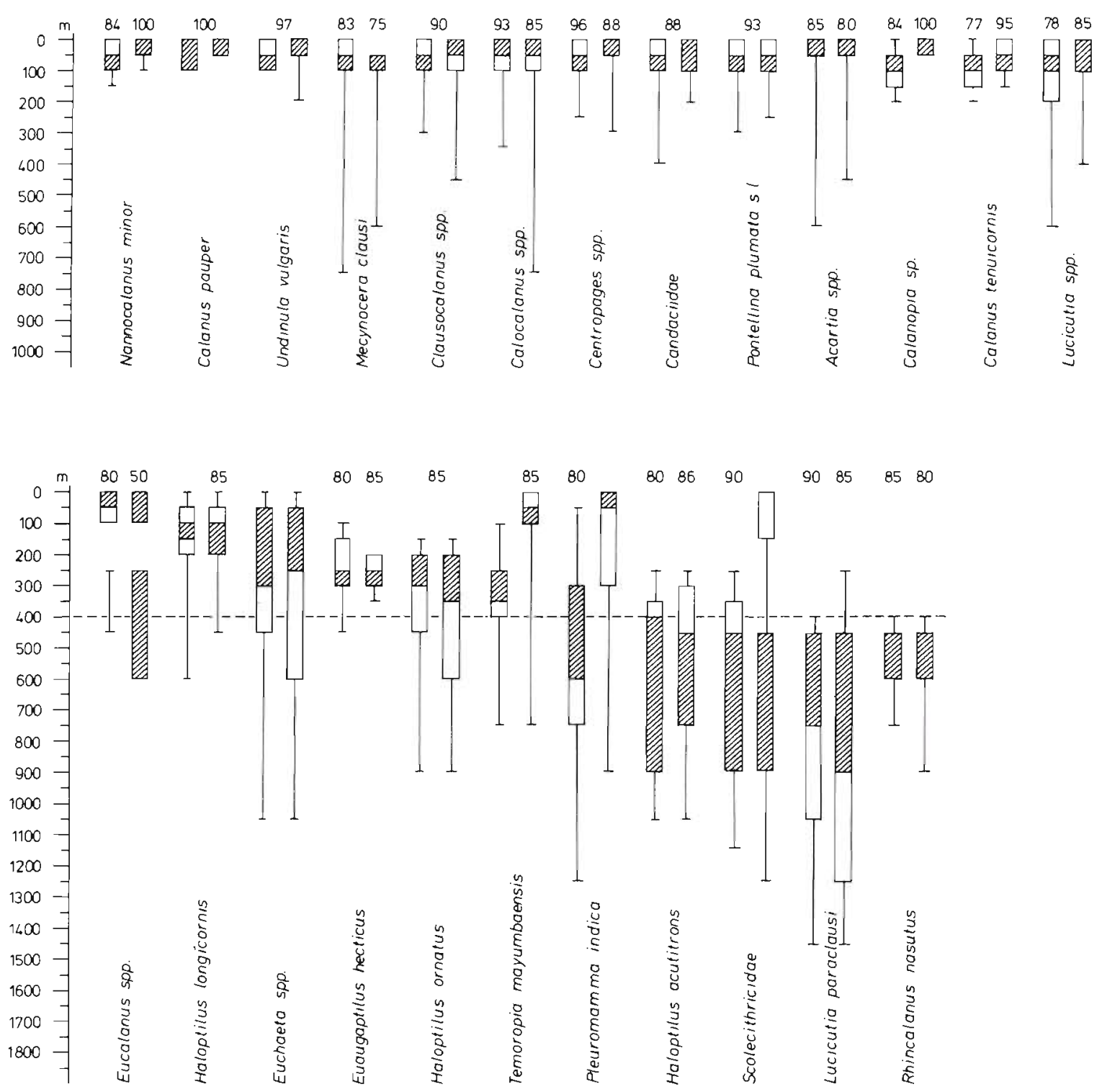

Fig. 6. Midday distribution (left bar for each species) and diurnal migration (total of left and right bars) of calanoid copepods. Above: Epipelagic species. Below: Interzonal species. Hatched portions of bars: depth ranges in which at least $50 \%$ (entire bar: layer in which at least $75 \%$ ) of the standing stock is congregated. True percentages are given above bars. Vertical lines indicate $97.5 \%$ of congregation. Broken horizontal line: approximate depth of minimum oxygen concentrations

Rhincalanus nasutus and Lucicutia paraclausi, become conspicuous.

In the upper bathypelagic zone (750 to $1,050 \mathrm{~m}$ ), a considerable part of the Lucicutia paraclausi and scolecithriciid stock (ca. $35 \%$ each) was found. However, none of these species achieved a clearly dominant position in the zooplankton of this layer (scolecithrids, $38.8 \%$; L. paralcausi, $10.1 \%$ ), and neither did any other species (Pleuromamma indica, 29.7\%; Table 5). Below approximately $1,050 \mathrm{~m}$, the water column was frequented by scattered specimens of these species and of a still undescribed (interzonal) ostracod
(Weikert, in prep.), which formed the 'deep-sea' plankton of the central Red Sea.

Vertical Segregation and Diel Migration of Calanoids
and Pteropods

There was a clear separation between the population cores of upper and lower interzonal species (Fig. 6). This border was located at $400 \mathrm{~m}$, where minimum oxygen values occurred (Fig. 2). The only exception was the population of Pleuromamma indica, which occupied both sub-zones. 
Within the 2 distributional groups, the population cores of different species showed considerable overlap. In part, this may be due to the relatively low sampling resolution, especially when 150 to $200 \mathrm{~m}$ thick layers had been sampled. For example, in the 450 to $600 \mathrm{~m}$ layer, also sampled at $50 \mathrm{~m}$ intervals at 3 stations, $95 \%$ of the resting Rhincalanus nasutus population resided in the 450 to $550 \mathrm{~m}$ layer, indicating a preference for minimum oxygen concentrations (Weikert, 1980). Congregations of epipelagic species are known to occur in layers $10 \mathrm{~m}$ thick or less (Cassie, 1963; Longhurst, 1976; Timonin, 1976)

On the other hand, a less concentrated distribution of subsurface calanoids is evident when Fig. 6 is compared with Fig. 7, which illustrates the distribution pattern of copepodite and adult stages belonging to individual species. The levels in which $50 \%$ of the populations of each stage were found are clearly different, suggesting that intraspecific competition may be greater than interspecific competition among subsurface calanoids.

Intraspecific segregation of life stages is also displayed by the pteropod, Limacina inflata (Fig. 7). Juveniles tend to avoid minimum oxygen concentrations and were therefore collected at shallower depths in the oxygen deficient zone. Brinton (1979) described a similar pattern for euphausiid populations in the oxygen minimum layer of the Eastern Tropical Pacific Ocean. The fact that juvenile and aduIt L. paraclausi exhibited a reversed distribution pattern does not provide evidence against the causative role of oxygen. Below the oxygen minimum layer, oxygen content increases continuously to about $2.0 \mathrm{ml}^{-1}$ at $1,200 \mathrm{~m}$ (Fig. 2)

The affinity of adolescent stages for higher oxygen concentrations is not evident in Haloptilus longicornis and $H$. acutifrons. A possible explanation is that adult males of the genus were counted together with adolescents. The preference of juvenile Pleuromamma indica stages for a greater oxygen saturation than the adults is evident when the concentration peaks of both age groups are considered (Weikert, 1980). No information is available on the ontogenetic segretation in Temoropia mayumbaensis, Euaugaptilus hecticus, and Rhincalanus nasutus, since juveniles were rarely found.

The completeness of separation between the assemblages of upper and lower interzonal calanoids remained unaffected by diel, vertical migrations (Fig. 6). If species migrate vertically, they generally cover only short distances and do not leave their habitat zones.

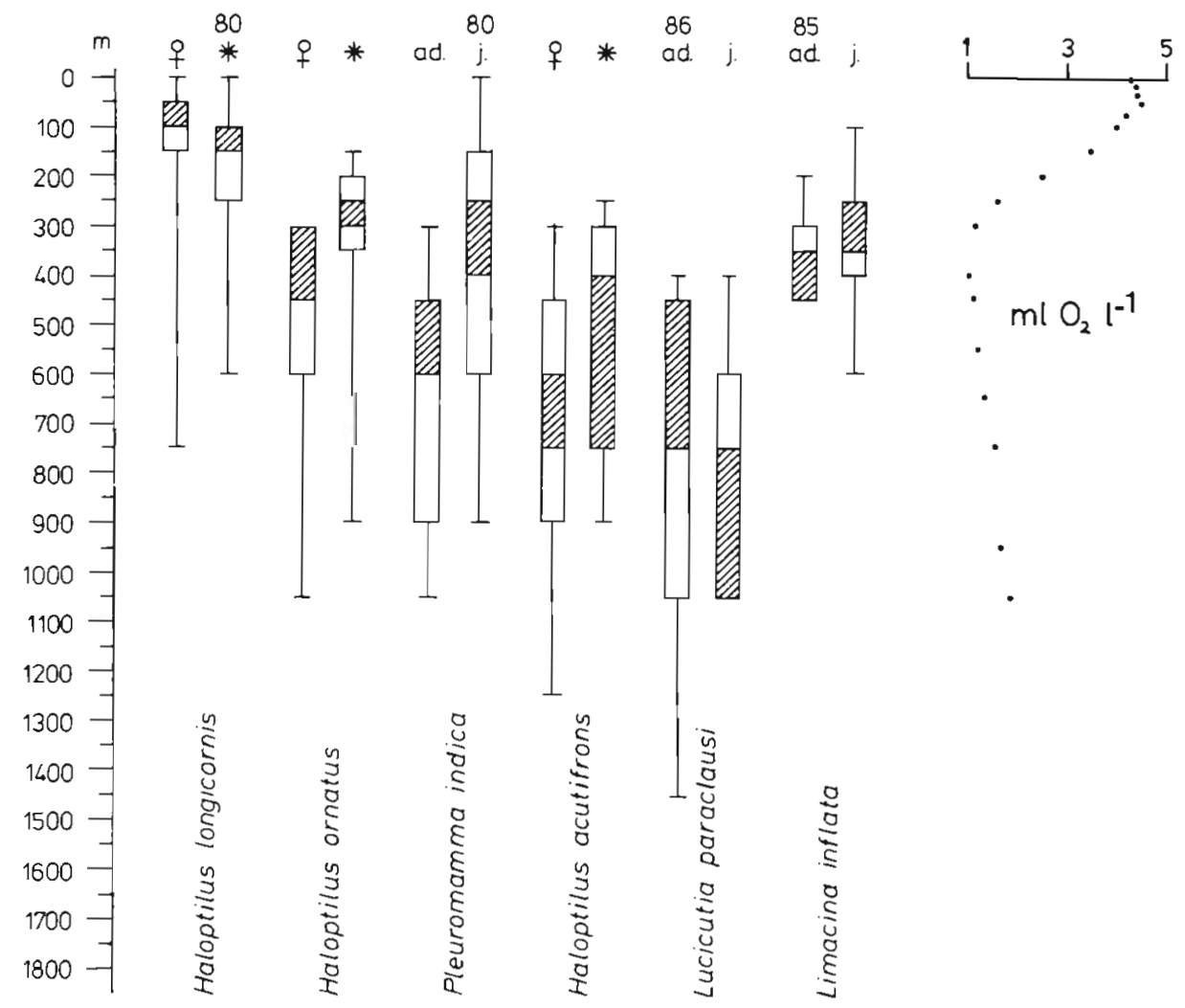

Fig. 7 Ontogenetic distribution of interzonal calanoid copepods and Limacina inflata (Pteropoda) at midday. Asterisks: populations consisting of juvenile and male stages. Other symbols as in Fig. 6 
Only a few interzonal species made long vertical migrations and interacted with the epipelagic assemblage. At midnight, $75 \%$ of the lower interzonal Pleuromamma indica population was encountered in the upper $300 \mathrm{~m}$. Within this layer, $50 \%$ of the individuals were aggregated in the upper $50 \mathrm{~m}$, accompanied by a remarkable number of scolecithriciids. Migrants from the upper mesopelagic zone include Limacina inflata, also concentrated in the upper $50 \mathrm{~m}$, and Temoropia mayumbaensis, that preferred the 50 to $100 \mathrm{~m}$ layer.

A much larger number of calanoid and euthecosomatous species in the central Red Sea, however, undertake diel migrations of about $100 \mathrm{~m}$ within the epipelagic zone (Fig. 6). This is also generally the case for the mesozooplankton (Delalo, 1966). The average biomass in the epipelagic zone at night (Fig. 5) did not exceed the value during daylight by more than $23 \%$. The numerical increase at night was even less $(13 \%)$. The difference in the percentages is caused by the larger size of migrating 'deep water' species, particularly the very abundant Pleuromamma indica.

No significant diel vertical migrations could be detected in the lower part of the bathypelagic zone due to the zooplankton depletion at depths greater than approximately $1,100 \mathrm{~m}$ (Figs. 5 and 6). If there were migrations, they would be insignificant and scarcely affect the mass transport.

\section{SUMMARY AND DISCUSSION}

According to the biological zonation scheme proposed by Vinogradov (1968), there are 3 distinct habitat zones in the central Red Sea. These are distinguished by their physical, chemical and biological properties, and are corroborated by recent findings (Weikert, 1981). In Fig. 8, a schematic illustration is presented that includes an outline of the vertical migrations of mesozooplankton. The habitat zones are as follows:

(1) The nutrient-poor epipelagic zone that extends from the surface to about $100 \mathrm{~m}$, thereby including the top of the thermohalocline. Quantitative analyses provided the following values: $11.3 \mathrm{mg}$ chlorophyll a $\mathrm{m}^{-2}$ (Weikert, in press); $12.7 \mathrm{~g}$ organic matter $\mathrm{m}^{-2}$ (65\% of the seston); $2.7 \mathrm{~g}$ wet weight $\mathrm{m}^{-2}$; and 19,880 specimens $\mathrm{m}^{-2}$ for the

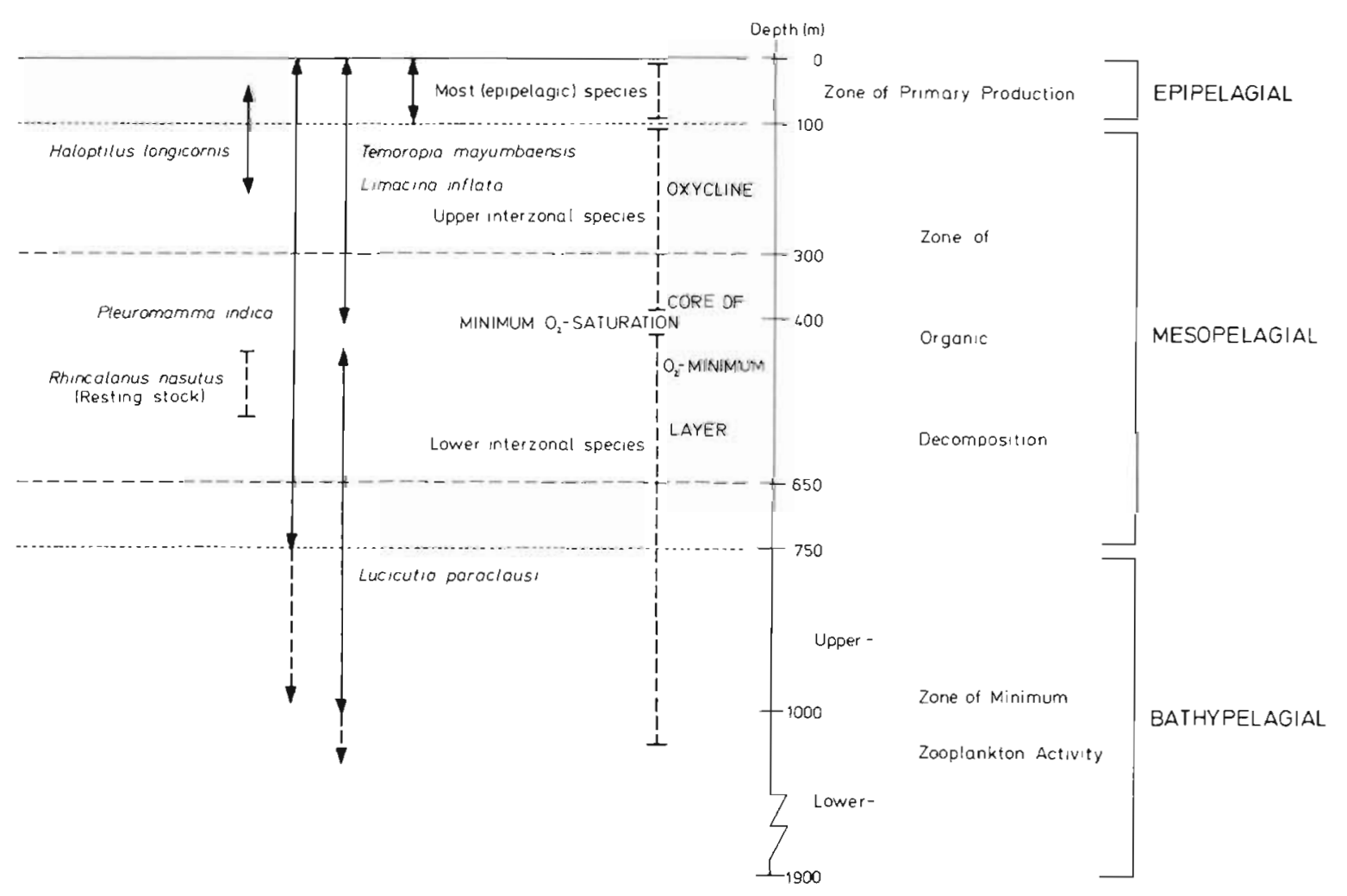

Fig. 8. Atlantis II Deep area habitat zones with characteristic zooplankton associations. Ranges of diurnal vertical migration by principal interacting species in November 1977 are exemplified by indicator calanoid copepod and euthecosomatous pteropod species. Broken vertical lines: habitat zones of significant zooplankton assemblages. Vertical arrows: amplitude of diel vertical migrations. Simplified illustration 
$300 \mu \mathrm{m}$ net zooplankton (mesozooplankton). Most of the zooplankton, including representatives of most species, congregated in the epipelagic zone and undertook diel, vertical migrations within this layer.

(2) The mesopelagic zone extends from approximately 100 to $750 \mathrm{~m}$. It occupies almost the same depth as the oxygen minimum layer and is characterized by conspicuous gradients in environmental and biological parameters. The strongest shoaling of isolines occurred in the upper $50 \mathrm{~m}$ of the oxycline, which is the 100 to $250 \mathrm{~m}$ layer. The reduction in the abundance of zooplankton is so drastic that only $1 / 7$ of the number and biomass in the 0 to $100 \mathrm{~m}$ layer was found between 100 and $200 \mathrm{~m}$.

The majority of the interzonal species congregate in the core of the oxygen minimum layer (300 to $650 \mathrm{~m})$, as determined in the cases of calanoid copepods and euthecosomatous pteropods. They produce the secondary maxima of individuals and biomass that are located in the daytime position of the DSL. The lower border of the DSL is at $750 \mathrm{~m}$ (Weikert, in press), the bottom of the mesopelagic zone as here defined.

The assemblages of upper and lower interzonal species are normally separated from each other by a layer of minimum oxygen concentration, about $20 \%$ of saturation. Few strong diel migrants are present in the two assemblages. The main calanoid and euthecosomatous species interacting with the epipelagic fauna are the upper interzonal Limacina inflata and Temoropia mayumbaensis, and the somewhat deeper dwelling Pleuromamma indica.

(3) The bathypelagic zone ( 750 to $\geq 1,850 \mathrm{~m}$ ) is a zone of strongly reduced zooplankton abundance and activity. Especially below 1,050 m, it is populated by only a few individuals belonging to interzonal species. No diel vertical migrations were observed below this depth
Copepods are the most abundant group throughout the water column. In the epipelagic zone, foraminiferans are also conspicuous. The dramatic decline in total zooplankton below $100 \mathrm{~m}$ is followed in mesopelagic waters by a markedly reduced diversity in calanoid copepods and euthecosomatous pteropods. This is quite unlike the 500 to $1,000(1,500) \mathrm{m}$ layer in the Sargasso Sea, where the maximum number of calanoid species were concentrated (Deevey and Brooks, 1977). In general, a large number of species is typical of deepsea plankton samples (Wishner, 1980a).

Within the mesopelagic zone, in the 200 to $250 \mathrm{~m}$ and 400 to $450 \mathrm{~m}$ layers, $17.5 \%$ and $25.5 \%$, respectively, of all the copepod material counted consisted of carcasses or moulted skins, compared to only 3.5 to $12.0 \%$ in other layers between the surface and $750 \mathrm{~m}$. The depth ranges of increased copepod debris coincide fairly well with the upper border of the oxygen minimum layer core and the layer of minimum oxygen saturation. These findings can be interpreted as evidence of increased environmental stress that apparently exists in the entire mesopelagic zone, judging from the low number of species and the predominance of one species in each association inhabiting the subzones of the oxycline and the core of the oxygen minimum layer.

No true deep-sea calanoid copepod fauna seems to inhabit the bathypelagic zone. Earlier faunistic investigations have demonstrated that there are also no bathypelagic chaetognaths (Furnestin, 1958) or euphausiids (Ponomareva, 1968; Weigmann, 1974). Extraordinarily low zooplankton values coincide with maximum percentages of carcasses (Table 7). These facts indicate environmental conditions extremely adverse to zooplankton survival. Even if applying a conversion factor of 4 to the $300 \mu \mathrm{m}$ samples, as proposed by Deevey (1971), who compared zooplankton counts of sample pairs from the upper $500 \mathrm{~m}$ obtained using $202 \mu \mathrm{m}$ and $363 \mu \mathrm{m}$ mesh, the zooplankton in the

Table 7. Numbers and percentages of all dead copepods and exoskeletons counted in Central Red Sea ( $300 \mu \mathrm{m}$ nets) and Sargasso Sea $(202 \mu \mathrm{m}$ nets; Deevey and Brooks, 1971). Living and dead copepods $=100 \%$. B: percentages of copepod debris in samples when contaminants in the living copepod portion have been omitted. Parentheses: values for each layer expressed in \% of the number at the next higher layer

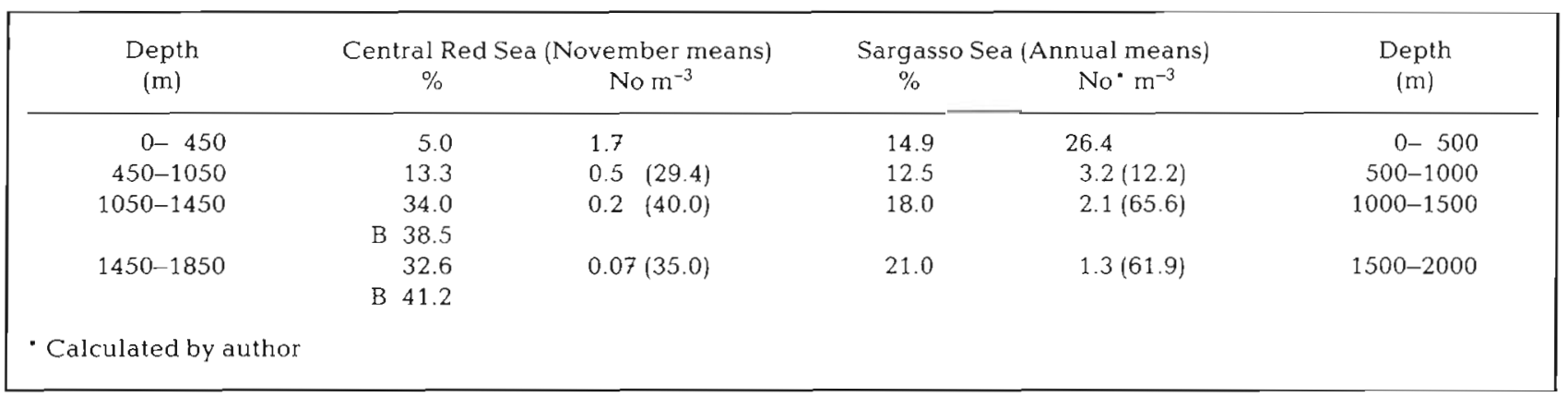


1,050 to $1,850 \mathrm{~m}$ layer of the central Red Sea amounts to only from $1 / 6$ to $1 /$ s of that in the Sargasso Sea (Table 8 ). The corresponding mean biomass of $0.05 \mathrm{mg}$ wet weight $\mathrm{m}^{-3}$ is comparable to values below depths of 4,000 to $6,000 \mathrm{~m}$ reported from the anticyclonic gyres in

Table 8. Standing stock of zooplankton (individuals $\mathrm{m}^{-2}$ ) in Central Red Sea (300 $\mu \mathrm{m}$ nets) and northern Sargasso Sea (202 $\mu \mathrm{m}$ nets; Deevey and Brooks, 1971). Numbers in parentheses corrected to eliminate errors assumed to have been caused by contamination

\begin{tabular}{|rcrr|}
\hline $\begin{array}{c}\text { Depth } \\
(\mathrm{m})\end{array}$ & $\begin{array}{c}\text { Central } \\
\text { Red Sea } \\
\text { (November } \\
\text { means) }\end{array}$ & $\begin{array}{c}\text { Sargasso } \\
\text { Sea } \\
\text { (Annual } \\
\text { means) }\end{array}$ & \multicolumn{1}{c|}{$\begin{array}{c}\text { Depth } \\
(\mathrm{m})\end{array}$} \\
\hline $0-450$ & 26,596 & 107,650 & $0-500$ \\
$450-1050$ & 3,020 & 13,950 & $500-1000$ \\
$1050-1450$ & $228(164)$ & 5,670 & $1000-1500$ \\
$1450-1850$ & $92(48)$ & 2,750 & $1500-2000$ \\
& & & \\
\hline
\end{tabular}

the Indian and Pacific Oceans (Vinogradov, 1968). This comparison is particularly significant since Vinogradov's data were obtained using $380 \mu \mathrm{m}$ nets.

The scarcity of plankton in the deep central Red Sea remains relatively constant throughout the year, albeit

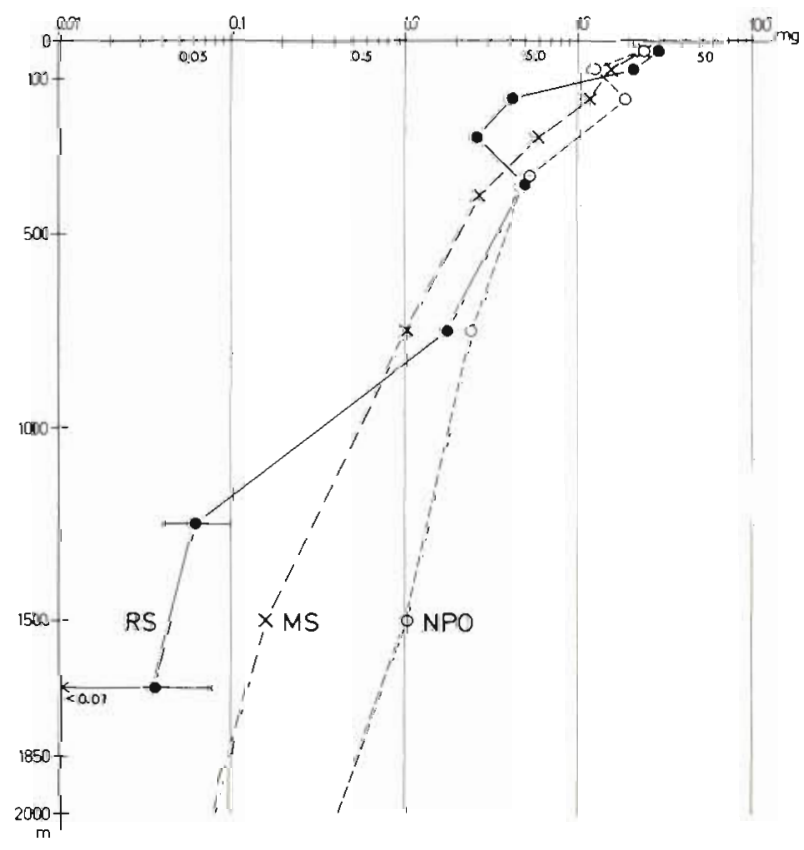

Fig. 9. Vertical distribution of mesozooplankton biomass ( $\mathrm{mg} \mathrm{m}^{-3}$ ) in oligotrophic regions of the tropical ocean (semilogarithmic scale). RS: Central Red Sea, mean values (bars denote ranges of values in deep water); MS: eastern Mediterranean Sea, single station in the Ionian Sea (Greze, 1963. An additional deep tow yielded $<0.1 \mathrm{mg} \mathrm{m}^{-3}$ for the 1,500 to 2,000 m layer); NPO: North Pacific Ocean, single station at $19^{\circ} 57^{\prime} \mathrm{N} 172^{\circ} 37^{\prime} \mathrm{E}$ (Vinogradov, 1968) weak seasonal fluctuations were detected in the 1,050 to $1,450 \mathrm{~m}$ layer (Weikert, 1981). Thus, the abrupt break in the zooplankton curve at about $1,050 \mathrm{~m}$ is obviously unique among the known distribution patterns in the oceans, indicating 'desert-like' conditions in the bathypelagic zone (Fig. 9).

The vertical distribution of zooplankton in the central Red Sea exhibits features to some extent similar to those ascribed by Vinogradov (1968) to other partially landlocked marine basins. Among these, the eastern Mediterranean Sea is noted for its scarcity of plankton in the deep-sea (Fig. 9). Except for the Red Sea, its deep waters have the highest temperature $\left(\geq 13.3^{\circ}\right.$; Wüst, 1961), and the hydrography (Oren, 1957) and planktonic biota (Kimor and Wood, 1975) of its oligotrophic surface zone are somewhat similar to those in tropical seas. However, the physical, chemical and planktological features are extreme in the Red Sea since it is completely isolated from the circulation of cold, deep ocean water. Its geographic isolation in the hot, arid climatic zone leads to unique 'heating' of the water body, even below the marked thermohalocline, to $22.0^{\circ}$ at the greatest depths, and evaporation causes high salinity ( $\geq 40.0 \%$ ) to prevail throughout the subsurface water. Such an environment is unfavourable to the deep-sea zooplankton species that are adapted to oxygenated waters at low temperature and 'normal' salinity (Weikert, 1980).

For interzonal species, however, better abiotic conditions seem to exist below $1,050 \mathrm{~m}$ than in their mesopelagic habitats, due to the higher oxygen values. Pleuromamma indica, the dominant interzonal calanoid copepod in the central Red Sea, is reported to be abundant in the Arabian Sea and the northern part of the Indian Ocean as deep as 1,400 to $1,600 \mathrm{~m}$ (Vinogradov and Voronina, 1961; Haq et al., 1973). Lucicutia paraclausi had previously been found only in the Atlantic Ocean at depths between 100 and $500 \mathrm{~m}$ (Park, 1970). The actual distribution of this species, however, is uncertain because earlier investigations did not distinguish it from L. clausi. Nevertheless, in the central Red Sea, interzonal species are obviously unable to survive in significant numbers in the lower bathypelagic niches, perhaps due to a lack of food.

Ultimately, a lack of food in the waters below the thermohalocline may be the limiting factor that forces the bulk of the subsurface plankton below the euphotic zone and discontinuity layer into the (upper part of the) oxygen minimum layer core. This situation is not common in the World Ocean (Fleminger, pers. comm.)

The scheme of vertical energy transfer in the upper $1,100 \mathrm{~m}$ in the central Red Sea seems similar to that in the oceans. The particulate material produced in the epipelagic zone may reach deeper layers only when incorporated into the relatively large animals from the 
mesopelagic zone. Plankton debris collected in the layers below $1,050 \mathrm{~m}$ originated most exclusively from transitional organisms, particularly the lower interzonal copepods Pleuromamma indica and Lucicutia paraclausi, and scolecithrid species. A predominance of exoskeletons from deep dwelling copepods was reported by Wishner (1980a) at sampling sites in the 'normal' cold, deep water of the tropical Eastern Pacific and the temperate North-east Atlantic Oceans.

However, in the central Red Sea, there seems to be no significant downward transport of organic matter by the 'ladder of migrations' (Vinogradov, 1953) deeper than approximately $1,100 \mathrm{~m}$. Due to the accelerated degradation of organic particles at high temperatures (Harding, 1973; Honjo and Roman, 1978), discussed by Thiel (1979) and Wishner (1980 b) relative to the peculiar environment of the Red Sea, few of these particles reach the deep waters by gravitational sinking. Compared with the Sargasso Sea, the amount of copepod debris in the central Red Sea tends to decrease more sharply at depths below 1,050 m (Table 7).

The reduced vertical transport of organic matter below about $1,100 \mathrm{~m}$ may explain the significantly smaller standing stocks of benthopelagic plankton (Wishner, 1980 b) and benthic fauna (Thiel, 1979) in the central Red Sea trough compared to similar depths in other seas characterized by low productivity.

Acknowledgements. I wish to express my thanks to many colleagues for various kinds of assistance. Dr. H.-C. John, Taxonomische Arbeitsgruppe an der Biologischen Anstalt Helgoland (BAH) in Hamburg, sacrificed his vacation to assist in the zooplankton sampling. Dr. H. Bäcker from Preussag AG in Hannover, the cruise leader, made the success of this investigation possible through his great competence and dedication. Mr. G. Klingebiel (Preussag) carried out the nutrient and oxygen determinations, and Mr. J. Post (Preussag) provided the bathysonde profiles. The work at sea was facilitated through the considerate and helpful collaboration of the officers and crew aboard R. V. 'Sonne'. Dr. K. Hülsemann (BAH), confirmed the identifications of a number of deep water copepods. Dr C. Heckman devoted much effort to improve the English text. I am grateful to the Saudi-Sudanese Red Sea Joint Commission, Jeddah, for funding the investigations.

\section{LITERATURE CITED}

Bäcker, H., Schoell, M. (1972). New deeps with brines and metalliferous sediments in the Red Sea. Nature Phys. Sci. 240, 103: 153-158

Bernhard, M., Moeller, F., Nassogne, A., Zattera, A. (1973). Influence of pore size of plankton nets and towing speed on the sample performance of two high-speed samplers (Delfino I and II) and its consequences for the assessment of plankton populations. Mar. Biol. 20: 109-136

Brinton, E. (1979). Parameters relating to the distributions of planktonic organisms, especially euphausiids in the eastern tropical Pacific. In: Angel, M. V., O'Brien, J. (eds.) Progr. Oceanogr. 8: 125-189

Casanova, B., Ducret, F., Rampal, J. (1973). Zooplancton de
Méditerranée orientale et de mer Rouge (Chaetognathes, Euphausiacés, Ptéropodes). Rapp. P.-v. Réun. Commn. int. Explor. scient. Mer Méditerr. 21: 515-519

Cassie, R. M. (1963). Microdistribution of plankton. Oceanogr. mar. Biol. 1: 223-252

Cooper, L. H. N. (1967). Stratification in the deep ocean. Sci. Prog., Lond. 55: 73-90

Deevey, G. B. (1971). The annual cycle in quantity and composition of the zooplankton of the Sargasso Sea off Bermuda. I. The upper $500 \mathrm{~m}$. Limnol. Oceanogr. 16: 219-240

Deevey, G. B., Brooks, A. L. (1971). The annual cycle in quantity and composition of the zooplankton of the Sargasso Sea off Bermuda. II. The surface to 2,000 m. Limnol. Oceanogr. 16: 927-943

Deevey, G. B., Brooks, A. L. (1977). Copepods of the Sargasso Sea off Bermuda: species composition, and vertical and seasonal distribution between the surface and $2000 \mathrm{~m}$. Bull. mar. Sci. 27: 256-291

Delalo, E. P. (1966). Distribution of the zooplankton biomass in the Red Sea and the Gulf of Aden, winter 1961/62 (Russ.). Okeanologicheskiye issled. 15: 131-139

Ducret, F. (1973). Contribution à l'étude des chaetognathes de la Mer Rouge. Beaufortia 20: 135-153

Ducret, F. (1974). Sur un chaetognathe voisin de Sagitta tropica observé en Mer Rouge. J. biol. Ass. India 16: 161-168

Furnestin, M. L. (1958). Quelques échantillons de zooplancton du Golfe d'Eilat (Aqaba). Bull. Sea Fish. Res. Stn Israel 16: $6-14$

Godeaux, J. (1974). Thaliacés récoltés au large des côtes égyptiennes de la Méditerranée et de la mer Rouge (Tunicata, Thaliacea). Beaufortia 22: 83-103

Gordeyeva, K. T. (1970). Quantitative distribution of zooplankton in the Red Sea. Oceanology, Wash. (Transl. of Okeanologiya, Mosk.) 10: 867-871

Grasshoff, K. (1969). Zur Chemie des Roten Meeres und des inneren Golfs von Aden nach Beobachtungen von FS 'Meteor' während der Indischen Ozean Expedition 1964/ 65. 'Meteor' Forsch. Ergebn. A, 6: 1-76

Grasshoff, K. (1976). Methods of seawater analysis, Verlag Chemie, New York

Greze, V. N. (1963). Zooplankton of the Ionian Sea (Russ.). Okeanologicheskiye issled. 9: 42-59

Halim, Y. (1969). Plankton of the Red Sea. Oceanogr. mar. Biol. 7: 231-275

Haq, S. M., Ali Khan, J., Chugtai, S. (1973). The distribution and abundance of zooplankton along the coast of Pakistan during postmonsoon and premonsoon periods. In: Zeitzschel, B., Gerlach, S. A. (eds.) The biology of the Indian Ocean. Ecological Studies 3. Springer, Heidelberg, pp. $257-272$

Harding, G. C. H. (1973). Decomposition of marine copepods. Limnol. Oceanogr. 18: 670-673

Hedgpeth, J. W. (1957). Classification of marine environments. In: Hedgpeth, J. W. (ed.) Treatise on marine ecology and paleoecology, Vol. I. Ecology. Geological Society of America. Mem. Geol. Soc. Am. 67: 17-28

Honjo, S., Roman, M. R. (1978). Marine copepod fecal pellets: production, preservation and sedimentation. J. mar. Res. 36: 45-57

Khmeleva, N. N. (1970). On the primary production in the Red Sea and the Gulf of Aden (Russ.). Biol. morja, Kiew 21: $107-133$

Kimor, B. (1973). Plankton relations in the Red Sea, Persian Gulf and Arabian Sea. In: Zeitzschel, B., Gerlach, S. A. (eds.) The biology of the Indian Ocean. Ecological Studies 3. Springer, Heidelberg, pp. 221-232 
Kimor, B., Golandsky, B. (1977). Microplankton of the Gulf of Elat: aspects of seasonal and bathymetric distribution. Mar. Biol. 42: 55-67

Kimor, B., Wood, E. J. F. (1975). A plankton study in the eastern Mediterranean Sea. Mar. Biol. 29: 321-333

Klinker, J., Reiss, Z., Kropach, C., Levanon, I., Harpaz, H., Shapiro, $Y$ (1978). Nutrients and biomass distribution in the Gulf of Aqaba (Elat), Red Sea. Mar. Biol. 45: 53-64

Lenz, J. (1971). Zur Methode der Sestonbestimmung. Kieler Meeresforsch. 27: 180-193

Levanon-Spanier, I., Padan, E., Reiss, Z. (1979). Primary production in a desert-enclosed sea - the Gulf of Elat (Aqaba), Red Sea. Deep Sea Res. 26: 673-685

Longhurst, A. R. (1976). Interactions between zooplankton and phytoplankton profiles in the eastern tropical Pacific Ocean. Deep Sea Res. 23: 729-754

Morcos, S. A. (1970). Physical and chemical oceanography of the Red Sea. Oceanogr. mar. Biol. 8: 73-202

Oren, O. H. (1957). Changes in temperature of the eastern Mediterranean Sea in relation to the catch of the Israeli trawl fishery during the years 1954-55 and 1955-56. Bull. Inst. Océanogr. Monaco 1102: 1-14

Ortner, P. B., Wiebe, P. H., Haury, L., Boyd, S. (1978). Variability in zooplankton biomass distribution in the northern Sargasso Sea: the contribution of Gulf Stream cold core rings. Fish. Bull. U.S. 76: 323-334

Park, T. S. (1970). Calanoid copepods from the Caribbean Sea and Gulf of Mexico. 2. New species and new records from plankton samples. Bull. mar. Sci. 20: 472-546

Ponomareva, L. A. (1968). Quantitative distribution of zooplankton in the Red Sea as observed in the period May to June 1966. Oceanology, Wash. (Transl. of Okeanologiya, Mosk.) 8: 240-242

Por, F. D. (1978). Lessepsian migration. Ecological Studies 23, Springer, Heidelberg

Postma, H. (1954). Hydrography of the Dutch Waddensea. Arch. Neérl. Zool. 40: 405-511

Roe, H. S. J. (1974). Observations on the diurnal vertical migrations of an oceanic animal community. Mar. Biol. 28: 99-114

Smith, R. L. (1976). Waters of the sea: the ocean's characteristics and circulation. In: Cushing, D. H., Walsh, J. J. (eds.) The ecology of the seas. Blackwell, Oxford, pp. 23-58

Sukhanova, I. N. (1969). Some data on the phytoplankton of the Red Sea and the western Gulf of Aden. Oceanology, Wash. (Transl. of Okeanologiya, Mosk.) 9: 243-247

Thiel, H. (1979). First quantitative data on Red Sea deep benthos. Mar. Ecol. Prog. Ser. 1: 347-350

Timonin, A. G. (1976). Study of the vertical microdistribution of oceanic zooplankton. Oceanology, Wash. (Transl. of Okeanologiya, Mosk.) 16: 79-82

Tranter, D. J. (1962). Zooplankton abundance in Australian waters. Austr. J. mar. Freshwat. Res. 13: 106-142

Vinogradov, M. E. (1953). The role of vertical migration of the zooplankton in the feeding of deep sea animals (Russ.). Priroda, Mosk. 6: 95-96

Vinogradov, M. E. (1968). Vertical distribution of the oceanic zooplankton. Acad. Nauk. SSSR Inst. Oceanolog. Moscow. (Transl. by Israel Program for Scientific Transl. Ltd Jerusalem, Keter Press, 1970)

Vinogradov, M. E., Voronina, N. M. (1961). Influence of the oxygen deficit on the distribution of plankton in the Arabian Sea. Oceanology, Wash. (Transl. of Okeanologiya Mosk.) 1. 670-678

Weigmann, R. (1974). Untersuchungen zur Zoogeographie der Euphausiaceen (Crustacea) des Roten Meeres. Helgoländer wiss. Meeresunters. 26: 225-237

Weikert, H. (1977). Copepod carcasses in the upwelling region south of Cap Blanc, N.W. Afrika. Mar. Biol. 42: 351-355

Weikert, H. (1980). The oxygen minimum layer in the Red Sea: Ecological implications of the zooplankton occurrence in the area of the Atlantis II Deep. Meeresforsch. 28: $1-9$

Weikert, H. (1981). The pelagic communities. In: Karbe, L., Thiel, H., Weikert, H., Mill, A. J. B. (eds.) Mining of metalliferous sediments from the Atlantis II Deep, Red Sea: pre-mining environmental conditions and evaluation of the risk to the environment. Environmental impact study presented to Saudi-Sudanese Red Sea Joint Commission, Jeddah. Hamburg, pp. 100-154

Weikert, H. (in press). On the plankton of the Central Red Sea - A first synopsis of results obtained from the cruises MESEDA I and MESEDA II. In: Proceedings of the 'Symposium on the coastal and marine environment of the Red Sea, Gulf of Aden and tropical western Indian Ocean', Khartoum, January 9-14, 1980, Sudan

Weikert, H., John, H.-C. (1981). Experiences with a modified Bé multiple opening-closing plankton net. J. Plankton Res. 3: $167-176$

Wheeler, E. H. (1967). Copepod detritus in the deep sea. Limnol. Oceanogr. 12: 697-701

Winter, A., Reiss, Z., Luz, B. (1979). Distribution of living coccolithophore assemblages in the Gulf of Elat (Aqaba). Mar. Micropaleontol. 4: 197-223

Wishner, K. F. (1980a). Aspects of the community ecology of deep-sea, benthopelagic plankton, with special attention to gymnopleid copepods. Mar. Biol. 60: 179-187

Wishner, K. F. (1980b). The biomass of the deep-sea benthopelagic plankton. Deep Sea Res. 27: 203-216

Wüst, G. (1961). Das Bodenwasser und die Vertikalzirkulation des Mittelländischen Meeres. 2. Beitrag zum mittelmeerischen Zirkulationsproblem. Dt. hydrogr. Z. 14: $81-92$

Yashnov, V. A. (1961). Vertical distribution of zooplankton biomass in tropical regions of the Atlantic Ocean (Russ.). Dokl. Akad. Nauk. SSSR 136: 705-708 